\title{
Aventuras na proteção à natureza: Narrativas da fiscalização da caça e da pesca no Rio Grande do Sul (1959-63)
}

\section{Elenita Malta Pereira'}

Numa fria tarde de domingo, no inverno de 1959, fiscais de caça e policiais militares trabalhavam juntos na BR-116, num trecho de Vacaria, cidade situada na regiáo nordeste do Rio Grande do Sul. Chefiados por Henrique Luiz Roessler (1896-1963), ordenavam que veículos considerados "suspeitos" estacionassem no acostamento para vistoriar seu interior. Um dos componentes do grupo, Luis Carlos Sanfelice, realizou a grande apreensão do dia, uma metralhadora:

um rapaz vinha num daqueles jipes Candango DKW, em manga de camisa, solta, com calor, embora fosse inverno, num Candango todo aberto. Eu parei o carro, me identifiquei. Ele disse: "eu to vindo de Brasília, não to caçando, não to fazendo nada". Mas atrás do banco dele eu vi um pacote muito bem embalado. Eu disse "que tem aí?" Ele "é coisa que to levando pra minha fazenda, em São Gabriel”. Ah, eu abri, era uma metralhadora! [Risos]. Parece que a gente fica com cheiro, instinto... O cara quis embravecer (...). Aí eu chamei o seu Roessler. O cara ofereceu dinheiro, fez o diabo pra levar a metralhadora, mas não conseguiu. E eu orgulhoso! Nós ficávamos num cruzamento atacando, parados. Os brigadianos atacavam, nós estávamos sempre com roupa civil. Aquela metralhadora, fiquei segu-

1 Doutoranda do Programa de Pós-Graduação em História da UFRGS. Bolsista Capes. E-mail: elenitamalta@gmail.com 
rando ela, me senti o próprio Stalone [Risos]. Mas depois fiquei com medo e entreguei prá ele [Roessler] (Entrevista de Sanfelice).

Esse foi apenas um dos inúmeros episódios que envolveram a fiscalização da caça e da pesca no Rio Grande do Sul nos anos 1950-60. Dispensado dos cargos de Delegado Florestal Regional do Serviço Florestal e de Fiscal de Caça e Pesca em dezembro de 1954 - ambos vinculados ao Ministério da Agricultura -, Roessler conseguiu uma credencial para continuar fiscalizando a caça e a pesca no âmbito da Secretaria Estadual de Agricultura, em 1955. Nesse mesmo ano, ele fundou a União Protetora da Natureza (UPN), primeira entidade não governamental do estado dedicada à proteção de todos os elementos naturais em São Leopoldo² . A partir de 1957, Roessler assumiu uma coluna semanal no Correio do Povo ${ }^{3}$, onde publicou cerca de 300 crônicas sobre questóes ambientais da época, tornando-se uma personalidade conhecida do público leitor do jornal.

Sanfelice, bem como outras pessoas que o acompanhavam nas diligências de fiscalização - a principal atividade de um Fiscal de Caça e Pesca -, eram funcionários da Secretaria de Agricultura designados para ajudar Roessler. Policiais militares, os "brigadianos", também eram requisitados, quando Roessler e seus auxiliares se dirigiam para a região nordeste do estado, especialmente às cidades que receberam imigração de grupos étnicos italianos, os quais apreciavam a "passarinhada", prato confeccionado com passarinhos, polenta e molho, duramente combatido por Roessler em sua atuação.

Neste artigo, enfoco as memórias de dois auxiliares que acompanharam Roessler nas viagens pelo estado, vistoriando veículos à procura de armas e caças ilegais, examinando barcos e pescadores para flagrar a pesca ilegal

2 Os primeiros sócios da entidade foram delegados e fiscais florestais que atuavam na fiscalização com Roessler. A UPN chegou a reunir cerca de 300 sócios (ROESSLER, Correio do Povo Rural, 18/11/1960), que contribuíam financeiramente para manter a entidade. Pelo que pude pesquisar, não havia reunióes regulares e a maior parte das açóes era planejada e executada pelo próprio Roessler. A educaçáo para a proteção à natureza era um dos pontos-chave da UPN, através da distribuição de panfletos com mensagens educativas e do proferimento de palestras de Roessler em escolas. Outro elemento considerado fundamental pela UPN era o aprimoramento da lei, necessário para tornar mais eficiente a repressão e a puniçáo aos que destruíssem a fauna e a flora.

3 Jornal fundado em 1895, em Porto Alegre. No contexto em que Roessler viveu, foi um dos jornais de maior circulação do estado. Nos anos 1930, "alcança a supremacia no Rio Grande do Sul, com mais de 35 mil exemplares ao dia” (Karawejczyk, 2008, p. 90). 
e multando os infratores, ou seja, aplicando rigorosamente os Códigos de Caça (Decreto-Lei no 5.894, 20/10/1943) e de Pesca (Decreto-Lei no 794, 19/10/1938), bem como as portarias anuais de caça ${ }^{4}$. Esse trabalho, no início impulsionado pelo estado, com a criação de órgãos e leis protetoras da natureza nos anos 1930 (Drummond, 1998, 1999), foi assumido por Roessler como um projeto pessoal. De 1939 até sua morte, em 1963, ele foi um dos protagonistas da luta pela proteção à natureza no Rio Grande do Sul. Em sua atuação, envolveu-se em episódios violentos, lutando contra hábitos culturais de parte da população, como a caça e a pesca.

O que era percebido como lazer, esporte (no caso da caça, especialmente de passarinhos) ou atividade necessária à sobrevivência (como a pesca, por exemplo) pelos seus praticantes, para Roessler era crime, contravenção. Mesmo que embasada nos diplomas legais, sua atuação rigorosa não era unânime: era admirada por uns, mas contestada por outros. Alguns caçadores de passarinhos chegaram a processá-lo judicialmente, o que levou a uma grande rivalidade.

Roessler, que representava o estado e era descendente de alemães, atingia a imagem dos caçadores de origem italiana chamando-os, em suas crônicas e documentação (cartas, panfletos da UPN), de "gringos", "tarados", "violentos", "loucos", "passarinheiros", "terríveis avicidas", "maus brasileiros”, "povo danado e fingido", entre outros nomes. Para Roessler, o gosto pela passarinhada seria um "vício inato", herdado dos antepassados de origem italiana; as geraçóes de descendentes nascidas no Brasil, em virtude dessa "maldita herança", seriam de "maus brasileiros", porque náo haviam conseguido livrar-se do vício.

Da mesma forma, da parte dos "italianos", foi construída uma imagem de Roessler como violento e covarde, ao nominá-lo de "cangaceiro", "espancador de indefesos colonos", "arrebatador de armas sem licença”, "crápula”, "cafajeste", "bandoleiro", que ia para os municípios de colonização italiana para praticar "atos selvagens", "tropelias", num "abuso de autoridade". Além disso, esse imaginário estava ligado à representação de Roessler como nazista, através da utilização de estigmas relacionados ao nazismo para referir-se a ele,

4 Anualmente, o Serviço de Caça e Pesca do Ministério da Agricultura mandava publicar em jornais de alcance estadual a portaria de caça, indicando as espécies e quantidades permitidas para o abate. Determinava também as espécies proibidas, entre elas todos os passarinhos. 
tais como "quinta coluna”, "porco", "agente da Gestapo", "agente com saudades de Dachau”, "racista”, "adepto de Hitler”, "monstro”, "Herr. Roessler”.

Interpretei essa rivalidade como uma versão localizada de uma espécie de "luta de representaçôes" (Bourdieu, 2007; Chariter, 2002) entre os grupos étnicos "italianos" e "alemães". Na disputa entre Roessler e os passarinheiros, ocorreu, também, a construção de estereótipos étnicos. Os dois "lados", ao utilizarem imagens negativas para se referirem aos rivais, construíram representaçôes - que podiam ser tão concretas quanto o "real" e mesmo vir a constituir o próprio real - com a intenção de diminuir, desvalorizar o "outro". Nessa "luta de representaçóes, no sentido de imagens mentais e também de manifestaçôes sociais destinadas a manipular as imagens mentais" (Bourdieu, 2007, p. 113), não importa se as representaçôes correspondem à verdade, mas sim se influenciam a construção de um imaginário para os grupos. No caso, tanto Roessler quanto seus inimigos queriam construir imagens negativas uns dos outros 5 . O choque entre visóes diferentes sobre a natureza fazia parte da dinâmica da fiscalização, como veremos nos depoimentos dos dois auxiliares.

Para uma pesquisa maior sobre Roessler, uma biografia histórica sob a perspectiva da história ambiental (Pereira, 2011), coletei depoimentos de pessoas ligadas a ele (parentes, conhecidos) e a entidades ambientalistas em Porto Alegre, Sáo Leopoldo e Novo Hamburgo (militantes atuais e remanescentes da época). Foram gravadas dez entrevistas, cada uma com duraçáo, em média, de uma hora, em diversas datas no decorrer do trabalho. O formato utilizado foi o da entrevista semidirigida; tinha preparado questóes amplas, a partir de estudo prévio, com a intenção de, no decorrer do encontro, permitir que o entrevistado aprofundasse os temas ou que sugerisse pontos de vista desviantes, o que deve ser objeto de atenção especial do historiador (Alberti, 2008, p. 185). Ao longo do artigo, transcrevo trechos de algumas dessas entrevistas, respeitando ao máximo as falas originais, mas com algumas edições, necessárias para que possam ser lidas.

As fontes orais são a forma mais importante de manifestação da memória. Paul Thompson defende o seu uso, na medida em que a entrevista torna-se uma oportunidade de descobertas em que "o meio ambiente imediato também adquire uma dimensão histórica viva do passado, o qual não

5 Para maiores detalhes dessa luta de representaçóes, consultar Pereira, 2012. 
é apenas conhecido, mas sentido pessoalmente" (Thompson, 1992, p. 30). Além de as entrevistas revelarem informaçóes e impressões não encontradas nos documentos escritos, trata-se, também, de compreender como a imagem de Roessler é percebida hoje, porque o depoimento, mesmo que remonte ao passado, é permeado pelo presente. Como observa Beatriz Sarlo (2005, p. 10), "el tiempo propio del recuerdo es el presente: es decir, el único tiempo apropiado para recordar y, también, el tiempo del cual el recuerdo se apodera, haciéndolo propio". Quem depóe está no presente, assim, o passado ganha vida porque vive aqui e agora, através da memória de alguém.

\section{"A felicidade de estar com ele"}

Tive a satisfação de encontrar duas pessoas que participaram da fase final das fiscalizaçôes, acompanhando Roessler em suas diligências. Luiz Carlos Sanfelice foi um dos motoristas do jipe cedido pela Secretaria de Agricultura para o transporte dos fiscais até as localidades onde a caça era realizada, e José Olavio Santana foi fiscal, subordinado a Roessler, atuando principalmente nas infraçóes da pesca. Sanfelice trabalhou com Roessler de 1959 a 1961; já Santana o acompanhou de 1962 a 1963. Ambos encontravam-se, na época, na faixa dos 20 anos. Eles atuaram em inúmeras diligências, porém separadamente, não chegando a se conhecer.

Sanfelice é advogado e vive em Porto Alegre. Nosso encontro deu-se no Tribunal de Contas, seu local de trabalho, em 13 de julho de 2010, e durou cerca de uma hora. Ele mostrou-se muito disposto e até mesmo honrado com a oportunidade de falar sobre um período "muito feliz" de sua vida. Em 1959, foi convidado a trabalhar no gabinete do Secretário da Agricultura, Deputado Federal Alberto Hoffmann (pelo Partido de Representação Popular-PRP). Sanfelice narrou-me que, cerca de um mês depois de assumir o cargo, Roessler apareceu na Secretaria pedindo sua ajuda para conseguir um veículo. $\mathrm{Na}$ época, ainda vigorava um acordo com os Estados Unidos, o chamado "Ponto Quatro", através do qual o estado recebeu "algumas

6 O "Ponto Quatro" foi lançado pelos Estados Unidos durante o governo Truman, em 1949, "um programa de ajuda técnica destinado às naçóes do Terceiro Mundo, particularmente às naçóes da 
unidades de caminhonetes, pick-ups internacionais, poderosas, possantes, que não tinham aqui”, cedidas para o trabalho de desenvolvimento agrícola, de movimentação de funcionários, agrônomos etc. Sanfelice e seus colegas conseguiram "uma caminhonete dessas para um fim de semana, para o seu Roessler. Ele ficou muito feliz quando conseguiu e disse: 'mas eu não tenho um motorista, e eu não posso dirigir porque eu tenho uma perna com uma

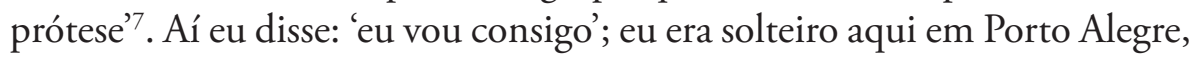
e saí uma vez com ele” (Entrevista de Sanfelice).

Na primeira saída, o destino foi Caxias do Sul. Como não conhecia “a maneira dele proceder", Sanfelice ficou surpreso e "encantado". Narrou que, quando passavam por pequenas propriedades da regiáo, Roessler dizia "para aqui", e descia para ver se não havia capivara morta ou outros animais protegidos que o fazendeiro tivesse matado. Se houvesse, "ele era rigoroso, prendia, autuava". Nessa primeira viagem,

a gente voltou com a pick-up carregada de armas, de capivara, de veado... e ele rigorosamente, ele chegava aqui, domingo de noite, recolhia a caminhonete. Na segunda-feira de manhá pegava a caminhonete e todo material apreendido. $\mathrm{O}$ que era armamento ia pra uma sala na diretoria de produção animal, no Menino Deus, antigo parque de exposiçóes, e o que era animais mortos, caça, ele dava pra Santa Casa, lar dos velhinhos defronte o Internacional, dava pra SPAM, não ficava com nenhuma perdiz, e eu fiquei quieto da primeira vez, não me atrevi a pedir, eu era um comedor de perdiz, adorava... Não me deu nenhuma, ele era rigoroso [com ênfase] (Entrevista de Sanfelice).

Dois finais de semana depois, Roessler voltou à Secretaria. A partir desse dia, tudo começou. Viajavam de maio a agosto, meses da temporada de caça no estado. Além de Caxias do Sul, iam para Vacaria, Rosário, onde "a

América Latina, com a finalidade de mantê-las fora do alcance do comunismo. Nessa região, a política de Washington tinha em vista o controle da produção de bens primários para abastecer as necessidades da sociedade norte-americana, ao mesmo tempo em que garantia o controle de um mercado consumidor para seus bens manufaturados. No Brasil, o Ponto Quatro teve forte repercussão. Em 1950, o governo brasileiro assinava com o norte-americano o Acordo Básico de Cooperação Técnica e, em 1953, o Acordo sobre Serviços Técnicos Especiais” (Ribeiro, 2009, p. 455).

7 Roessler usava uma prótese de madeira, pois tinha perdido a perna direita até o joelho num acidente com o jipe, em uma das fiscalizaçóes, na estrada de Farroupilha a Bento Gonçalves, em maio de 1952. 
turma caça muito", Itaqui, São Borja, Cachoeira, Santa Cruz, Santa Vitória do Palmar, Chuí etc. Sempre voltavam carregados de armas ilegais. Em certa ocasião, foram para a região de Santa Maria. Sanfelice disse a Roessler que ali não havia caça, entretanto ele queria realizar outro tipo de fiscalização:

Daqui a pouco, nós passando - tem muita lavoura de arroz na altura de Cachoeira [do Sul], e adiante de Santa Cruz - ele disse "para aqui", ele disse, "tá vendo essa lavoura aí?", "Sim, tô vendo", "Tá vendo que tem garça na lavoura?", "Tô, tô vendo", "Se tem garça, é porque tem peixe, se tem peixe é porque a bomba que faz a sucção da água tá puxando peixe, peixe pequeno, que náo tem força pra resistir", eram bombas com cano desse tamanho [Sanfelice mostra um círculo grande com as máos]. O Seu Roessler: "Você fica de calção" - Fomos até o local onde estava a sede do bombeamento - "e você entra, e vê se a tantos metros onde tem a bomba, tem um anteparo, uma tela, que tem ter tal tamanho na abertura da rede pra não deixar passar alevinos nem os peixinhos pequenos, filhotes, etc. se não tiver, você me diz". Mas assim, meu Deus do céu: rio Taquari, rio Jacuí, rios poderosos, essas bombas fundas, três, quatro metros de fundura, e na ocasião nós estávamos com uma Kombi. Bom, eu tirei a roupa, fiquei de calção, e fui, louco de medo de me topar com aquilo. A margem do rio é assim, eles fazem um puxado prá dentro, póem a bomba aqui, e o rio tá aqui, né? E ali, é um lugar meio escondido, não vai ter uma cobra, alguma coisa aí. E aí, eu entrei, meio com medo, e aí mergulhei ai, e senti, disse: "olha, a malha é mais ou menos tanto". E o seu Roessler: "não pode ser, tá vindo peixe, tão ali as garças”, daí multou o camarada. Aí eu voltei pra caminhonete e tentei me secar, ele disse "Nem te veste, que já vai ter outra”. E assim nós fomos toda aquela região, até São João do Polesine, Vale Vêneto, toda aquela região já subindo a serra, fiscalizando tudo (Entrevista de Sanfelice).

A “matança” de filhotes de peixes nas lavouras de arroz, devido às bombas de sucção instaladas em rios e açudes para transportar água até as plantaçóes de arroz, foi criticada por Roessler inúmeras vezes. Na crônica "Proteção aos peixes" (Correio do Povo, 22/02/1957), Roessler denunciou que, embora existissem leis que obrigavam os orizicultores ao uso de telas de filtro na ponta dos canos de sucção, a maioria não as utilizava. Por isso, milhares de ovas e filhotes de peixes eram atraídos e esmagados pelo mecanismo. 
O problema era tão grave, que Roessler procurou a revista Lavoura Arrozeira $^{8}$ para divulgar apelo aos produtores de arroz do estado. Na ocasião, Roessler regressava de uma longa viagem de fiscalização, na qual observou que "foram reiniciadas as irrigaçóes dos arrozais, sem que nas válvulas da maioria das bombas tivesse sido adaptado qualquer dispositivo protetor dos filhotes de peixes" (Lavoura Arrozeira, Março/1957, p. 27). Roessler informou ao repórter que "os condutos estavam fervilhando de alevinos, especialmente piavinhas e douradinhos (...) os quais morrerão por ocasião da suspensão dos regadios, o que é do agrado dos plantadores de arroz, visto que os muitos milhões de pequeninos peixinhos se transformarão em ótimo adubo". Através da revista, estava "apelando ao espírito de compreensão e boa vontade dos orizicultores, para que coloquem imediatamente a armaçáo telada com malhas de 1 centímetro, exigida por lei, para impedir a entrada dos alevinos nas lavouras de arroz" (Lavoura Arrozeira, Março/1957, p. 28).

Apesar dos perigos inerentes à fiscalização, Sanfelice obedecia às ordens de Roessler: "era uma voz de líder, uma voz de comando que você não podia se recusar". A descrição de Sanfelice nos mostra como era feita a fiscalizaçáo dos rios: in loco; só mergulhando é que se poderia saber se o arrozeiro estava cumprindo a lei ou não.

Também na região de Santa Maria, próxima a Vale Vêneto, ocorreu outro episódio interessante, lembrado por Sanfelice:

ia indo um carroceiro, numa carreta daquelas bem antigas com roda de madeira, e duas juntas de bois, e o cara com uma vara enorme, com a qual ele tocava as juntas de bois. Ele [Roessler] disse "para", ele desceu, pegou aquela vara e tac!, pegou o facáo e cortou a ponta. Eu: "o que é que ouve?", aí ele me contou que na ponta dessa vara - eram varas longas, de 4 metros - eles colocavam pregos, e com esse prego eles cutucavam o boi pra ele andar mais depressa, porque o boi é lento. O seu Roessler falou "Olha, eu devia te fincar, quantas vezes você fincou esse prego no boi, cem vezes eu devia te fincar esse prego". Outra vez, eu não vi, mas eu soube: ele desceu do ônibus aqui no centro [de Porto Alegre] e ia lá na Secretaria pra falar comigo, no gabinete, na Júlio de Castilhos, que apesar daquela perna dele - a prótese era bem primitiva, pelo que me consta, de madeira,

8 Revista editada pelo Instituto Rio-Grandense do Arroz (IRGA). Tinha sede em Porto Alegre e era especializada em assuntos agronômicos. 
legítima perna de pau, ele caminhava bem - e topa com um carroceiro dando de relho num cavalo, pois ele parou e com o relho deu no cara... [risos] (Entrevista de Sanfelice).

Cena muito semelhante foi narrada por Centeno (2006, p. 13-14), em que Roessler também teria surrado um carroceiro com o próprio relho com o qual este batia em seu cavalo. Sanfelice lembrou que, muitas vezes, eles atuavam nas estradas, parando os veículos, "atacando todo o trânsito, até ônibus com placa Porto Alegre-Rio de Janeiro, ele atacava [risos]”. Numa dessas ocasióes, na ponte sobre o Rio das Antas, "ele arrumou uma encrenca danada com a Ordem dos Capuchinhos", de Caxias do Sul, "porque vinha um ônibus pequeno, com estudantes seminaristas capuchinhos, que vinham de um piquenique lá adiante do Rio das Antas". Roessler mandou o ônibus parar e, no seu interior, "tinha uma Flaubert - uma arma de repetição, de calibre 22, um calibre pequeno pois ele apreendeu a arma dos capuchinhos, porque não tinha registro. Não tinha caça, mas ele apreendeu" (Entrevista de Sanfelice).

Um dos pontos altos da entrevista com Sanfelice foi a descrição detalhada de como era a dinâmica das saídas, dos acampamentos, o que comiam, como dormiam. Esse relato minucioso, permeado de afeto e saudade, pode esclarecer um pouco mais sobre esses momentos, táo aguardados por Roessler. Sua narrativa é a representação das memórias que são construídas hoje, numa combinação entre passado e presente, no entanto, são extremamente importantes para a nossa história, porque não estão comprometidas com nenhuma instituição ou movimento. E foi com muita emoção que Sanfelice lembrou-se das "batidas":

Quantas vezes nós acampamos... Eu era solteiro, morava num apartamento, tinha uma cama de ferro, lençol de cima, cobertor, travesseiro, você não vai acreditar, eu pegava o colchão e enrolava com tudo como estava, passava uma corda, e jogava dentro da caminhonete. Quando chegava nos acampamentos, era sempre ele que pegava um facáo, cortava um galho de uma árvore, fazia uma forquilha, para armação da barraca e jogava uma lona em cima. Colocava minha cama de um lado, a cama dele do outro (Entrevista de Sanfelice).

Com o acampamento montado, as instalações eram bastante rústicas. Roessler "tinha uma caixa, que tinha chaleira, salame, sal, as coisas... Mas 
bem primitivo". Adquiriam víveres, em geral, "no final de uma tarde, já noite, (...) num bolicho mais próximo que tinha. Comprava salame, linguiça, alguma coisa desse tipo, um pedaço de queijo, se havia, e íamos lá, e montávamos o acampamento da forma mais primitiva possível" (Entrevista de Sanfelice). As refeiçóes eram preparadas de modo primitivo: a água era fervida em fogo de chão,

não era liquinho, tinha que arrumar graveto, fazer o fogo. Quando a água tava fervendo, ele punha o café dentro d'água direto. Depois ele pegava um pedaço daquela lenha queimada, assim meio na forma de brasa, jogava ali dentro da chaleira. Aquela brasa eu acho fazia uma espécie de serviço de decantação, então toda a poeira do café ficava presa embaixo na chaleira e a gente pegava os canecos de alumínio, enchia de café, açúcar, salame e pão. E era essa nossa janta e o nosso café da manhá. De meio dia, enquanto a gente ficava numa esquina de uma estrada fazendo o serviço, ele ia lá, fazia um fogo no chão (...) nem tripé de ferro ele tinha, botava umas pedras e botava a panela ali, picava um charque, uma coisa com arroz, e era aquele o almoço. Fazia uma espécie de carreteiro. Da forma mais simples e mais primitiva mesmo, no entanto são as coisas que eu tenho mais saudade nos meus 72 anos de vida, porque marcantes, saudáveis, gostosos (Entrevista de Sanfelice).

Em outras ocasióes, deixavam pinhão cozinhando enquanto fiscalizavam, "pinhão novinho, fresquinho, que, às vezes, a gente mesmo colhia embaixo do pinheiro". Em geral, na volta, saíam da cidade em que se encontravam "já tarde da noite de domingo", chegando em Porto Alegre

de madrugada, num bagaço, com aquelas Kombi vagabundas que andavam quando muito 50, $60 \mathrm{~km}$ por hora. Mas, no calor dos 20, 21 anos... na segunda-feira de manhã, o gabinete me tolerava. Aí eu dormia, só chegava tarde. Mas sabe quando você fazia isso e você sentia que você participou de alguma coisa digna, bonita, limpa, como era o serviço dele em prol da natureza? Então junto com o seu Roessler eu conheci esse lado diferente do campo, das lagoas, dos banhados... Eu vivia sujo com ele, porque entrava em banhado, entrava em rio, subia em morro... mas era a minha felicidade estar com ele. Eu me emocionei a ponto de chorar comigo mesmo quando eu soube da morte dele (...). E algumas 
vezes eu saía daqui na sexta-feira de tardezinha, e dormia lá na casa dele, prá nós sairmos 3:30, 4 horas da manhã, prá pegar os caçadores, sendo que caçador sai cedo, então dependendo do roteiro que a gente ia, saía sábado de madrugada. E quando ele parava no meio da estrada, perto desses banhados aí prá baixo, ele dizia: "para aqui, para aqui, porque tem alguém amoitado lá”, porque o caçador de marreca tem que ficar muito quieto, e é tão grande a vontade de caçar, que ele póe aquelas roupas, se abriga, um frio danado, póe uma marrequinha de borracha, alguma coisa prá atrair, um apito, mas era mesmo, ele [Roessler] não errava uma. Parava lá, entrava eu no banhado, se tinha cobra, eu nem tava com roupa adequada, não sei como nunca peguei uma pneumonia. Eu fazia sinal prá ele, e ele ia lá (Entrevista de Sanfelice).

Como podemos perceber, os finais de semana de batidas são lembrados intensamente por Sanfelice como uma aventura. As fiscalizaçóes com Roessler mostraram-lhe outro lado do Rio Grande do Sul que ele não conhecia, apesar de que já tivesse, antes disso, viajado para várias cidades do estado com seu pai. Chama atenção o caráter rústico das instalaçóes - barraca erguida com forquilha "feita na hora" -, da alimentação, comprada em "bolicho", do café decantado com lenha, do fogo com gravetos, do carreteiro cozido na beira da estrada e do pinhão colhido pelas próprias mãos. Justamente essa rusticidade era o que tornava a comida - e a aventura - mais saborosa. A felicidade de "estar com ele" era tanta que, quando casou, em 1960, Sanfelice teve que negociar com a jovem esposa a ida aos acampamentos: "nos finais de semana eu queria sair com o seu Roessler, mas a minha mulher me xingava, então a gente ia a baile; um fim-de-semana a gente ia ao baile da Engenharia, da reitoria, mas na sexta-feira seguinte eu saía com o Seu Roessler" (Entrevista de Sanfelice).

Sanfelice afirmou que, de certa forma, foi educado por Roessler: "Até eu conhecer o Seu Roessler eu matava tudo que vinha pela minha frente... [risos]... se mexia, morria. Fui grande caçador. Depois eu continuei caçando, mas aí era um caçador superdisciplinado, não matava nada além da cota, nem perdigão, capivara”. Segundo Sanfelice, não portavam arma de fogo nas diligências. "Tinha no carro um facão. Nem cassetete, nas vezes que saiu comigo, não (...). Muitos conheciam a fama dele, e baixavam a bola” (Entrevista de Sanfelice). 


\section{"Um homem de respeito"}

Fala semelhante ouvi de José Olavio Santana: "todo mundo conhecia ele” e o respeitava. Santana foi, além de fiscal, pescador e mecânico; hoje, é aposentado. Para entrevistá-lo, fui até sua casa, em São Leopoldo, na tarde de 20 de outubro de 2010. Segundo Santana,

O "velho" era um homem de muito respeito. Se ele chegava assim, a pessoa já... [faz gesto de recolhimento]. Ele tinha autonomia e autoridade. Ele chegava assim, com educação, falava e a pessoa já temia. Ele não discutia, só a presença dele, a autonomia dele, da delegacia, do exército, da brigada, autoridade, então o pessoal já sabia. Só a presença, já conheciam ele, no Estado do Rio Grande do Sul todo mundo conhecia ele. Por isso que eu digo, era um homem de respeito, tivesse um homem daquele hoje aqui, não existia certas coisas por aí. Ele não era ditador, só que era um homem de respeito. $\mathrm{E}$ não adiantava dizer que não, porque ele tinha a força, né? Então o pessoal já sabia. Não era medo, tinham respeito por ele, respeito (Entrevista de Santana).

Os depoimentos de Sanfelice e Santana coincidem em alguns pontos, mas são discordantes em outros, até porque o tipo de fiscalização de que participaram foi diferente. Enquanto Sanfelice acompanhou, principalmente, "saídas" para fiscalizar a caça e as bombas de sucção, Santana teve mais contato com diligências que envolviam contravençôes da pesca. Além disso, a memória de cada pessoa seleciona o que é mais significativo para si, aspecto a ser considerado quando se utiliza a metodologia da história oral, inclusive positivo para a análise, pois permite perceber a riqueza e a diversidade das falas.

Um ponto de divergência é quanto ao porte de armas. Enquanto Sanfelice afirmou nunca ter visto, Santana disse que os fiscais andavam armados: "todos nós andávamos armados. Nunca foi preciso atirar, a gente usava só prá respeito". E o revólver de Roessler, "acho que era um 44, desse tamanho assim [mostra algo grande]" (Entrevista de Santana). Talvez dependendo do local em que a fiscalização era realizada, houvesse ou náo o porte de arma de fogo.

Santana participou das últimas fiscalizaçóes de Roessler, cerca de "um ano e pouco antes de ele morrer, lá por 62-63. Depois eu fui também com 
o Milton (...). Ele [Roessler] já tinha o itinerário, ele já sabia aonde íamos. Vinham dar parte aqui. O pescador, o caçador, ele se sente prejudicado, vinha entregar os outros. A gente andava de barco ou de jipe". Fiscalizavam tanto a caça como a pesca ilegal. A pesca dava mais trabalho:

A gente apreendia arma, material de pesca, rede, tarrafa, espinhel. Depois era levado; deixava um tempo aqui, né, como nome da pessoa, tudo com intimação, o local e a hora. Daí ficava amarrado junto com o material apreendido. Ficava uns dias na casa dele, depois ia tudo pra Porto Alegre. Era lá no Cais do Porto. Aí a pessoa vinha procurar, se pagava os impostos e a multa, era devolvido, senão, ia prá lá. Minha função era como fiscal. Ia junto e também podia sair [sozinho], se ele mandasse. Ele era o chefe (...). A pesca tinha mais problema do que a caça. Não existia ladrão, não roubavam as redes, porque ficava preso. $\mathrm{O}$ problema era que o pessoal pescava, mas não pagava os impostos. O peixe que era apreendido era contado, a qualidade, o cara tem que assinar uma intimação e tem que doar ou num hospital, ou numa casa de caridade, ou num presídio. A caça também. A fiscalizaçáo recolhia e depois tinha que aparecer o que foi apreendido num hospital, casa de caridade ou num presídio. A pessoa responsável por esses lugares tinha que assinar que recebeu tal quantidade de tais espécies de peixe (Entrevista de Santana).

Outra divergência é que, para Santana, a pesca era mais problemática do que a caça, ao contrário do que Sanfelice lembrou. Como trabalhava durante a semana, Santana participava das saídas aos sábados e domingos. Contou que saíam à noite ou de madrugada, acompanhados de policiais, os "brigadianos". As viagens de jipe eram para o "lado de Morro Pelado, Sapiranga, Caí, Montenegro, rio Cadeia. A gente saía, às vezes de manhá, ou de noite. Se saía de manhâ, voltava de noite, de madrugada”. Perguntei se acampavam, e ele disse que não, que nunca havia acampado. Quanto à alimentação, durante as fiscalizaçóes, era providenciada por Roessler:

Ele levava a merenda, ele tinha um bornal, entáo ali dentro ele levava um sanduiche e refrigerante, essa grapete, gasosa, ele levava. No sanduíche tinha pão, queijo, salame, era bem... bem servido. Quando era o dia todo, então a gente parava num restaurante prá comer. Nas saídas ele fazia um memorando e mandava pra Porto Alegre. Náo sei quem pagava, se era ele ou o governo, porque ele devia receber alguma verba prá isso (Entrevista de Santana). 
Santana narrou que Roessler fazia um teste para escolher os fiscais. Ele "levava duas, três vezes junto, pra ver como a pessoa se portava. Ele deixava aquele que tava aprendendo se envolver, pra ver como ele tratava as pessoas. Ele ficava só cuidando, daí ele chamava pra ser fiscal com ele, outros não, muitos ele não aceitou". O entrevistado demonstrou orgulhar-se de ter feito parte do grupo seleto dos cinco fiscais de Sáo Leopoldo. O primeiro teria sido "Lauro Maria, depois foi João Correa, Manoel Chaves, o Milton - filho dele, e o último fui eu, o último que ele levou". Santana é o único vivo do grupo. Numa das diligências, em Caxias do Sul, houve um tiroteio entre fiscais e caçadores, e Manoel Chaves foi baleado numa perna. Chaves recuperou-se, mas passou a caminhar mancando depois do incidente (Roessler, 1999, 32-33).

Lauro Maria, o primeiro fiscal, contou a Santana um caso ocorrido em uma das andanças em Caxias do Sul que, pela veia cômica, merece a transcrição:

Meu compadre Lauro contou que uma vez - o Roessler não falava sobre isso, os outros [fiscais] é que falavam - tavam fazendo um enterro, tinha seis caras levando um caixão, lá em Caxias. E o velho desconfiou: "só seis carregando o caixão, não vem ninguém atrás aí, fazendo o enterro, o cortejo". Aí os fiscais e os brigadianos desceram do jipe, os caras quiseram correr, daí calçaram eles - contado pelo Lauro, eu não tava junto, pena ele não estar vivo prá contar isso. Aí quando eles quiseram correr, o Roessler mandou prender eles, cercar eles, aí foram abrir o caixão, tava cheio das armas deles e de passarinhos lá dentro [risos] (Entrevista de Santana).

É claro que não há nenhuma comprovação de que esse episódio tenha acontecido de fato, porém náo considero absurda a ocorrência de algo assim. Na documentação analisada para a pesquisa maior, encontrei o relato de uma fiscalização na localidade de Vila Seca, interior de Caxias do Sul, na qual Roessler mandou parar um caminhão que vinha de São Francisco de Paula com seis passageiros. O representante do grupo, interrogado por Roessler "se vinham de caça", respondeu que não, que todos eram sócios de uma empresa fabricante de muniçóes de guerra, e que haviam saído para experimentar granadas de sua produção. Ele mostrou aos fiscais três caixas que estavam na carroceria do caminhão, afirmando conterem o artefato. Porém, Roessler desconfiou e insistiu em revistar o veículo. As caixas foram abertas e foi constatado por todos que elas estavam repletas de passarinhos (Serviço de 
Caça e Pesca, 08/05/1949). Pela verdadeira paixão que muitos descendentes de imigrantes italianos nutriam pelas passarinhadas, é bem possível que se tornassem criativos nas maneiras de disfarçar a caça, chegando a ponto de encenarem um enterro. Destaca-se o "faro" de Roessler para essas situaçóes, o que Sanfelice também confirmou, dizendo que "ele não errava uma”.

\section{"O velho Roessler"}

Perguntei aos entrevistados como era a voz de Roessler. Como não restou nada gravado, imagem ou voz - apenas poucas fotografias - fiquei, muitas vezes, durante a pesquisa, curiosa sobre esse aspecto. Penso que a voz de uma pessoa é um aspecto importante, porque revela traços de sua personalidade, a maneira como trata os outros, e sempre dá um colorido a mais a um personagem, tratando-se de uma biografia. Para Santana, "a voz dele era calma, ele era um homem calmo, era de pouca conversa, não era de muita conversa. Se tinha que dar um conselho, ele dava, se achasse que tu fez alguma coisa errada, te chamava atenção, fazendo ver o que era e o que não era (...). Ele era muito seguro". Já para Sanfelice,

ele tinha voz de um locutor de noticioso, firme, bonita, muito segura. Sabe, quando a pessoa não importa sobre que assunto estivesse falando era muito... passava segurança, parece que fazia parte do sangue, da estrutura dele... é lamentável não ter nada gravado dele... Não gesticulava, quando falava; passava tranquilidade quando falava (Entrevista de Sanfelice).

As duas falas concordam que a voz de Roessler unia calma e segurança ao mesmo tempo. Ela também inspirava obediência militar. Para Santana, "era a mesma coisa que um tenente mandando um sargento, entấo ele faz, né?", e para Sanfelice, "era uma voz de líder, uma voz de comando que você não podia se recusar. Ele, se fosse um general de exército, teria a tropa mais disciplinada do mundo, mais aguerrida...”. A postura de Roessler devia inspirar obediência a seus subordinados, e isso ocorria de forma consentida, em uma relação de hierarquia. Roessler havia sido Delegado Florestal do Estado e era Fiscal de Caça e Pesca. Havia muitos anos, toda sua atuação, de cunho policial, conferia-lhe poder e autoridade perante os jovens fiscais. Segundo 
Santana, "ele era um homem autoritário, mas não era arrogante. Ele gostava que o cara fosse justo, da lei. Se tu errasses, chamava a atenção, aí era mais rígido: 'não me faça mais isso, senão vou te mandar embora', ele era franco".

Creio que a experiência adquirida - que o tornou quase um mito no Vale do Rio dos Sinos - fez com que Roessler tivesse uma postura que motivava o respeito e a obediência, sem que fossem necessárias muitas palavras. Até porque ele não era de muita conversa. Santana lembrou-se de uma frase que atribuiu a Roessler: "A boca calada não tem resposta prá dar. Quer dizer que ele não ia discutir com ninguém. Ele ficava quieto (Entrevista de Santana)". Se o fiscal não respondesse às agressóes, o fiscalizado não teria como retorquir.

O mito do "velho Roessler", como ele era chamado em São Leopoldo, fazia as crianças correrem. Para Santana,

Ele não era um cara ruim, era um homem de respeito. Mas se tavam caçando de bodoque, e ele chegava aqui, mas... Deus me livre, corriam tudo, se escondiam até debaixo da cama de medo dele, né? Chamavam ele de "velho Roessler", todo mundo. Se alguém avisava "o velho Roessler tá por aî”, mas... Todo mundo já ficava com medo! (Entrevista de Santana)

No entanto, não eram só as crianças que caçavam (e sentiam medo), mas também "homens caçavam de bodoque, uns barbados, homem casado". Em São Leopoldo, ocorria "a mesma coisa dos gringos. Comiam, faziam festa com passarinhos. A mesma coisa que faziam em Veranópolis”. Só não faziam tanto "por causa do Roessler" (Entrevista de Santana). Isso nos mostra que os descendentes de alemães, portugueses, africanos ou de outros grupos étnicos também poderiam apreciar os passarinhos como petisco, não apenas os italianos.

Além do respeito, devia haver o medo. E um medo alimentado pelo próprio Roessler, procurando estar presente na cidade e em torno do Rio dos Sinos, nos locais onde costumavam ocorrer as contravençôes avisadas pelos informantes e, ao mesmo tempo, presumidas devido aos seus anos de experiência. Santana relatou que "se ele achasse que tinha que sair, não tinha dia, não tinha hora. Se dessem parte de uma matança de bichos, ou tivessem pegando peixe... não tinha hora, não tinha dia. Se ele desconfiasse de qualquer coisa, ele ia também, convocava a turma e iam" (Entrevista de Santana). Como não havia dia certo, existia sempre a iminência de o "velho Roessler" estar por perto, vigiando. 
Essa onipresença também foi relatada por Arno Kaiser, membro da entidade Movimento Roessler ${ }^{9}$, entrevistado por mim em 20 de maio de 2008. Kaiser não conheceu Roessler pessoalmente, mas manteve relaçóes com alguns antigos membros da UPN, como o Padre Clemente, o professor Kurt Schmeling e o filho de Roessler, Milton. Segundo Kaiser,

ele pegava as pessoas de surpresa, ele era meio onipresente, porque sabia de muita coisa, porque ele tinha uma rede de muitas pessoas que moravam, pescadores, agricultores, fazendeiros, pessoas que simpatizavam com as ideias dele, que o mantinham mais ou menos informado, né? Foi esse povo que ele juntou prá fundar a Uniáo Protetora da Natureza (Entrevista de Kaiser).

Havia uma espécie de advertência: "olha que o velho Roessler vai te pegar” (Entrevista de Kaiser). Maria Luiza Roessler disse-me que, muitas vezes, ao se apresentar para pessoas idosas como neta de Roessler, ouviu: "Ah, o 'velho Roessler' me perseguiu, correu atrás de mim, por causa dos passarinhos" (Entrevista de Maria Luiza). Para o jornalista Alceu Feijó, "ele tinha uma capacidade incrível, né? Faziam comentários assim, que lá em Livramento, o cara ia dar um tiro num veado, primeiro olhava pra ver se o Roessler não tava por perto... O cara dava um tiro e o Roessler tava em cima dos caras" (Entrevista de Feijó). Parece que o "velho Roessler", como advertência iminente, ficou gravado na memória coletiva do Vale do Rio dos Sinos, provocando tantas lembranças parecidas (os entrevistados vivem na região).

Os informantes, segundo Santana, "vinham dar parte dos outros, sabe? Era um entrega-entrega... era "cacoete", aquele que entrega os outros, jacaré...” (Entrevista de Santana), inclusive por motivos de desavenças pessoais. Se não fossem os "cacoetes", talvez o trabalho de Roessler não fosse tão bem-sucedido, porque, evidentemente, sozinho não teria como saber de tantas transgressóes ocorridas em todo o estado. A rede de informaçóes

9 Entidade ecologista fundada em Novo Hamburgo, em 16 de junho de 1978. O Movimento Roessler surgiu com a Operação Hermenegildo, uma das grandes batalhas do movimento ecologista no Rio Grande do Sul, organizada em abril de 1978, em função da mortandade de peixes e mariscos na praia do Hermenegildo, em Santa Vitória do Palmar. Houve uma coalizão de forças entre diversas entidades ecologistas gaúchas. O impacto da luta foi táo importante, que pessoas simpáticas ao tema da ecologia resolveram fundar essa entidade em Novo Hamburgo. O nome Movimento Roessler foi escolhido como forma de homenagear Roessler, considerado "pioneiro da ecologia" na regiấo. Ver mais em Pereira, 2011. 
tecida por ele dava suporte essencial para sua atuação, possibilitando sua onipresença. A probabilidade de encontrar o "velho Roessler" era uma ameaça constante, que deve ter freado muitos ímpetos de caça e pesca ilegais.

\section{"O fiscal mais eficiente do Brasil"}

Sanfelice demonstrou em sua entrevista que sente muita saudade do tempo da fiscalização: "minha vida com ele foi saudável, foi bonita, tenho imensa saudade...”. Para Sanfelice, Roessler

era um homem de uma retidão, de uma dignidade que me ensinou muito, o respeito pela natureza, o respeito pelas pessoas, mas a intransigência em relação à vida natural, o que ele queria de bem um passarinho! Ele conhecia tudo, tico-tico, sabiá, coruja, beija-flor, e andando assim a gente vinha 4,5 tipos de corujas, [Roessler explicava:] essa faz toca assim essa assado... Foi defensor do Rio Grande do Sul como uma pátria de muitas espécies.

Um dia eu vou me encontrar com ele lá em cima e nós vamos fazer fiscalização... [Muitos risos]... o São Pedro deve ter uns caçadorezinhos safados por lá... [risos]. (Entrevista de Sanfelice)

\section{Para Santana, Roessler}

foi o fiscal mais eficiente do Brasil todo. Porque ele tinha autoridade e sabia o que tava fazendo, e dava autoridade pros fiscais também. Com ele não tinha nada, é, é, não é, não é. Ele tinha uma coisa que ele fazia antes de fazer as coisas: fazia certo, matutava primeiro. Depois ele fazia; agora ele era justo, né? Não podia mentir prá ele. Se tivesse pescando ou caçando e não sabia, ou tava pescando pros filhos comer, "hoje tu vai embora, mas outra vez, vai ser recolhido tudo. Vai lá e paga os teus tributos, que não tem problema, que nem os outros pagam também”. (Entrevista de Santana)

Os dois entrevistados ressaltaram o caráter justo, reto, eficiente e patriótico da atuação de Roessler. Isso vem ao encontro da imagem que circula sobre o fiscal na maior parte do estado, cujo rigor no cumprimento das leis ambientais foi inúmeras vezes elogiado por chefes, amigos e colaboradores. 
Após sua morte, essa imagem inspirou membros de entidades ecologistas fundadas nos anos 1970, como a Associação Gaúcha de Proteção ao Ambiente Natural (AGAPAN), a União Protetora do Ambiente Natural (UPAN) e o Movimento Roessler, que o instituíram como patrono.

Os depoimentos de Santana e Sanfelice, além de demonstrarem o quanto de afeição Roessler lhes inspirava, esclareceram sobre o cotidiano das diligências informaçóes que não encontrei na documentação analisada. Sanfelice, emocionado, lembrou que dormiam em barracas, preparavam as refeiçóes de maneira rústica, e até colhiam pinhóes direto das árvores. Já Santana narrou que iam e voltavam no mesmo dia, viajando no barco de Roessler por diversos rios do estado. Percebi na fala dos dois ex-fiscais que as lembranças daquele tempo guardam uma nostalgia, um sabor de aventura. $\mathrm{O}$ jeito primitivo de lutar contra os contraventores, nas horas inesperadas, foi lembrado por ambos com muito orgulho. Essa memória foi relembrada como um troféu, uma honra, por terem participado de algo bom, positivo, em prol da natureza.

Além disso, os dois auxiliares de Roessler vivenciaram experiências violentas de cruzamento entre natureza e cultura. Através de suas falas, é possível perceber o quanto era difícil exercer uma funçáo que ia de encontro a práticas de lazer muito apreciadas por parte da populaçáo, como a caça e a pesca. Ocorria o choque entre duas visóes opostas da natureza. Para os caçadores, caçar ou pescar além da cota, fora do período legal, ou mesmo caçar passarinhos, não era crime, era um hábito cultural; já para os fiscais, era uma contravençáo.

Os “contraventores", sentindo-se prejudicados, utilizavam artimanhas para driblar os fiscais: mentiam, disfarçavam a roupa, escondiam a caça e, quando isso não funcionava, ofereciam suborno. Na tentativa de ficar com o produto obtido em momentos de diversão (peixes e animais), ou com os artefatos de caça e pesca (armas, redes, espinhéis etc.), tornavam-se criativos, como o grupo que inventou o teste de granadas. Por outro lado, essas artimanhas podem ser pensadas como instrumentos de resistência dos caçadores e pescadores atingidos. A autoridade dos fiscais, cumprindo rigorosamente a lei, atrapalhava o prazer dessas pessoas.

Roessler acreditava-se imbuído de um ideal, de uma missão: a proteção à natureza. Por isso, não era facilmente enganado nem se deixava subornar. Para ele, o sentido de cumprimento do dever era mais forte: se a lei determinava, aplicava-a sem concessóes. Esse rigor levou a tiroteios e lutas corporais, 
além de violência simbólica, através de duros xingamentos entre ele e caçadores das cidades de colonização italiana no estado durante as fiscalizaçóes. No entanto, episódios violentos como esses são, hoje, motivo de saudosas recordaçóes de Sanfelice e Santana. Trabalhar ao lado de um "defensor da natureza", além de representar algo "bom", era uma peripécia constante, irresistível para os jovens de 20 e poucos anos. Valia a pena correr os riscos, diante de caçadores e pescadores revoltados, porque, acima de tudo, para eles, acompanhar Roessler significava uma nobre aventura.

\section{Fontes Orais}

FEIJÓ, Alceu. Entrevista à autora. Novo Hamburgo, 17/11/2010.

KAISER, Arno. Entrevista à autora. Porto Alegre, 20/05/2008.

ROESSLER, Maria Luiza. Entrevista à autora. São Leopoldo, 07/06/2008.

SANFELICE, Luiz Carlos. Entrevista à autora. Porto Alegre, 13/07/2010.

SANTANA, Olavio. Entrevista à autora. São Leopoldo, 20/10/2010.

\section{Referências}

ALBERTI, Verena. Histórias dentro da História. In: PINSKY, Carla. Fontes Históricas. São Paulo: Contexto, 2008.

BOURDIEU, Pierre. A identidade e a representação. Elementos para uma reflexão crítica sobre a ideia de regiāo. In: BOURDIEU, Pierre. O poder simbólico. Rio de Janeiro: Bertrand Brasil, 2007.

BRASIL. Decreto-Lei no 794, de 19 de outubro de 1938. Código de Pesca. Disponível em: <http://www6.senado.gov.br/legislacao/ListaPublicacoes. action?id=23799>. Acesso em 30 de dezembro de 2011.

BRASIL. Decreto-Lei no ${ }^{\circ}$ 5.894, de 20/10/1943. Código de Caça. Disponível em: <http:// www2.camara.gov.br/internet/legislacao/legin.html/textos/visualizarTexto.html?ideNorm $\mathrm{a}=415862 \&$ seqTexto $=1$ \&PalavrasDestaque $>$. Acesso em 20 de dezembro de 2011 . 
CENTENO, Ayrton. Roessler: o primeiro ecopolítico. Porto Alegre: JÁ Editores, 2006.

CHARTIER, Roger. À beira da falésia: a história entre certezas e inquietude. Porto Alegre: Ed. da Universidade/UFRGS, 2002.

DRUMMOND, José Augusto. A legislação ambiental brasileira de 1934 a 1988: comentários de um cientista ambiental simpático ao conservacionismo. Ambiente \& Sociedade. n. 3 e 4, 1998-1999, p. 127-149.

KARAWEJCZYK, Mônica. O voto da costela: o sufrágio feminino nas páginas do Correio do Povo (1930-1934). Dissertação de Mestrado. PPG História. Porto Alegre: PUCRS, 2008.

LAVOURA ARROZEIRA. A diminuição da riqueza pesqueira e os arrozais. Porto Alegre, n. 123, Março/1957 (Museu de Comunicação Social Hipólito José da Costa).

PEREIRA, Elenita Malta. Um protetor da natureza: Trajetória e Memória de Henrique Luiz Roessler. Dissertação de Mestrado. Programa de Pós-Graduação em História. Porto Alegre: UFRGS, 2011.

PEREIRA, Elenita, WEBER, Regina. Roessler Vs. Bird Hunters: "Passarinhada" and Ethnic Conflicts in the South of Brazil. Miradas en Movimiento. Special Volume Naturally Immigrants. Espacio de Estudios Migratorios, Michigan University, Jan 2012.

Disponível em: <http://espaciodeestudiosmigratorios.org/es/miradas-en-movimiento-mem/ volumenes/naturally-immigrants/cat_view/74-volumen-especial>.

RIBEIRO, Maria das Graças Martins. A USAID e o ensino agronômico brasileiro: o caso da Universidade Rural do Estado de Minas Gerais. Boletim do Museu Paraense Emílio Goeldi-Ciências Humanas. Belém, v. 4, n. 3, set/dez. 2009.

ROESSLER, Henrique. Em causa própria. Correio do Povo Rural. Porto Alegre, 18/11/1960.

ROESSLER, Henrique. "Proteção aos peixes". Correio do Povo. Porto Alegre, 22/02/1957.

ROESSLER, Maria Luiza. O homem do rio. Porto Alegre: AGE, 1999.

SARLO, Beatriz. Tiempo passado: cultura de la memória y giro subjetivo - una discussión. Buenos Aires: Siglo XXI Editores, 2005.

SERVIÇO DE CAÇA E PESCA. Auto de Infração aplicado por Roessler. Vila Seca - Caxias do Sul, 08/05/1949 (Arquivo privado de Henrique Roessler).

THOMPSON, Paul. A voz do passado: História oral. São Paulo: Paz e Terra, 1992.

Resumo: Este artigo tem como objetivo analisar as memórias de dois auxiliares de Henrique Luiz Roessler que o acompanharam na fiscalização da caça e da pesca no Rio Grande do Sul entre os anos 1959-63. Mesmo tendo vivenciado episódios de violência física ou de grande 
risco de vida, hoje esse período é lembrado saudosamente, sendo sua participação nesses episódios considerada motivo de orgulho para ambos. Seus depoimentos, além de narrarem o cotidiano da fiscalização e alguns detalhes de como esta era realizada, possibilitam entrever o conflito maior em que estavam envolvidos. No embate entre os hábitos culturais de parte da população e o rigor na aplicação dos Códigos de Caça e Pesca, ocorria um choque entre visões muito diferentes da natureza.

Palavras-chave: fiscalização da caça, fiscalização da pesca, história oral, memória.

\title{
Adventures in protection to nature: Narratives of supervision of hunting and fishing in Rio Grande do Sul (1959-63)
}

\begin{abstract}
This article aims to analyze the memories of two assistants of Henrique Luiz Roessler who accompanied him in the supervision of hunting and fishing in Rio Grande do Sul between the years of 1959 and 1963. Even though they have experienced episodes involving physical violence or death threats, today this period is remembered by them with joy, and their participation is a source of pride for both. Their testimonies, as well as narrating the daily supervision and some of its details, show a glimpse of the larger conflict in which they were involved. In the clash between cultural habits and the rigorous application of the Codes for Hunting and Fishing there was the conflict between very different visions of nature.
\end{abstract}

Keywords: hunting supervision, fishing supervision, oral history, memory.

Recebido em: 10/02/2012

Aprovado em: 07/07/2012 